\title{
Short term effects of fire intensity and fire regime on vegetation dynamic in a tropical humid savanna (Lamto, central Côte d'Ivoire)
}

\author{
A. B. N'Dri ${ }^{1^{\star}}$, J. Gignoux ${ }^{2}$, A. Dembele ${ }^{1}$, S. Konate ${ }^{1}$ \\ ${ }^{1}$ Unit of Training and Research in Natural Science, Center for Research in Ecology, Lamto Station of Ecology, Nangui Abrogoua \\ University, Abidjan, Côte d'Ivoire; *Corresponding Author: ndri.brigitte@yahoo.fr \\ ${ }^{2}$ BIOEMCO (Laboratoire de BIOgéochimie et Ecologie des Milieux COntinentaux) Laboratory, UMR-7618, University Pierre et \\ Marie Curie, CNRS, ENS, Paris, France
}

Received 22 September 2012; revised 24 October 2012; accepted 6 November 2012

\section{ABSTRACT}

We tested the effects of different fire regimes (with different fire date and fuel load) on grass growth, tree debarking and topkill in a Guinea savanna of West Africa. Different fire intensities were simulated on two plots of 3.72 ha each, delimited in two shrubby savanna of the Lamto reserve (Côte d'Ivoire). Two fire regimes were applied, the mid-season fire (January) and the late fire (April). Two fuel levels (single: $\mathrm{C} 1$ and double: C2) have been used. For each fire regime, fire intensity was determined. It increases with the fuel quantity $\left(1259 \pm 356 \mathrm{~kW} \cdot \mathrm{m}^{-1}\right.$ and $3380 \pm 1472 \mathrm{~kW} \cdot \mathrm{m}^{-1}$ respectively for $\mathrm{C1}$ and $\mathrm{C2}$ ). The regrowth speed of grasses is also dependent on the fuel quantity (grasses). It increases with it and is higher after the mid-season fire than the late fire. The average intensity of the mid-season fire $\left(2966 \pm 2233 \mathrm{~kW} \cdot \mathrm{m}^{-1}\right)$ is not significantly different from that of the late fire (1673 \pm $\left.1124 \mathrm{~kW} \cdot \mathrm{m}^{-1}\right)$. Damages or debarking caused by fire on adult trees were recorded and are linked to fire intensity. Those damages appear to initiate the external cavity observed on trees, known to be detrimental to tree trunk mechanical resistance. They generally affect adult trees of Crossopteryx febrifuga species which is also the most commonly hollowed species. Mid-season fire remains the recommanded fire regime because it insures a faster regrowth of grasses which leads to the maintenance of equilibrium between grasses and trees.

Keywords: Fire Intensity; Fuel Load; Fire Regime; Savanna Vegetation

\section{INTRODUCTION}

Fire is a natural process, integrated into the function of many ecosystems, particularly savannas. The study of fire ecology focuses on understanding the processes that link fire behavior and its ecological effects. This includes the relationship between fire, living organisms, and the physical environment [1]. Fires strongly influence ecosystem dynamics and are subject to the effects of climate variability on two time scales [2]: 1) on the long-term (1 year): primary production of grasses constitutes the bulk of the fuel; 2) on the short-term ( 10 days): local weather conditions, a short period before fires have a considerable influence on their dynamics. We therefore expect a possible impact of climate change on the dynamic of fires, while their effects on ecosystems are not yet fully characterized.

In the Guinea savanna region of West Africa, the phenomenon of savanna invasion by trees despite the annual occurrence of fire is a major concern, as in other American [3] Australian [4] and African [5] savannas. Indeed, the reasons for such changes in vegetation are not well known. The effect of climate change and changes in fire intensity (severity) are suggested [3,6].

The lack of information on fire intensity makes it even more difficult to understand its impact on vegetation, specially in a climate change context. Fire intensity or the rate of energy release, is an important descriptor used in studies of fire behavior and the ecological impacts of fires [7]. Fires are considered more intense in forests than in savannas [8-11], but there is no estimation available to make the difference between fire intensity in dry $v s$. wet savanna. In humid tropical savanna, the high rainfall ensures the development of a biomass that allows relatively violent fires [12]. Woody cover is controlled by fire in those savannas [13-16], but changes induced by 
fire in the vegetation structure is not sufficiently studied.

In Africa, every year, on average, respectively $10 \%$, $38 \%$ and $70 \%$ of the Sahel, Sudanese and humid Guinea zone, of savanna burn [17]. In West African savannas, fire is well integrated with human habits such as hunting, traffic and livestock [8]. Large savanna areas are burnt each year, but very few studies are devoted to fire ecology unlike in Australia where several long-term experiences were established to measure and understand the impact of fire on living organisms [18-21].

The ability of plants to persist after fire by sprouting is known to be decisive for tree demography [22]. However, fire can affect adult trees [23-25]. N'Dri et al. [26] showed that mortality of tree stems increased with fire intensity. The same authors showed that fire interacts with termites to cause external openings on adult tree trunks. This study suggested that fire could damage trees, which would favor their attack by termites to cause internal cavities. Fire could cause thereafter the opening of internal cavity and the breakage of these trees. Our aim here is to test the hypothesis that fire plays an important role in causing possibly life-threatening damage on tree trunks. Despite the importance of fire in determining the occurrence of savannas, it remains difficult to understand how its seasonal nature and intensity interact to influence the vegetation structure, while the severity of a fire depends on its intensity and on the season in which it occurs [1]. Fire behavior is influenced by many factors [27], among which one of the most important is fuel quantity and quality $[28,29]$. In this study carried out in the Lamto savanna, fire intensity was determined by reference to the quantity of fuel and the season. The impact of fire intensity and its regime on adult trees and on the speed of regrowth of the grass layer were evaluated.

\section{MATERIAL AND METHODS}

\subsection{Study Area}

This study was conducted in the Lamto reserve, located in the center of Côte d'Ivoire $\left(6^{\circ} 13^{\prime} \mathrm{N}, 5^{\circ} 02^{\prime} \mathrm{W}\right)$, in the transition zone between semi deciduous forest and the Guinea savanna [30]. The average yearly rainfall reaches $\sim 1200 \mathrm{~mm}$ in the region and is used to classify the Lamto climate in the rainy climates regime [31]. The climate is of a sub-equatorial type with four seasons: a long rainy season from March to July, a short dry season in August, a short rainy season from September to November, and a long dry season from December to February. Each year, the fire (mid-season fire) is set by scientists in the Lamto reserve during the long dry season (in January). In this reserve, the fire has a stabilizing function and explains the persistence of the savanna in an area where the climate favors the existence of forests [8, 30]. This mid-season fire is the usual fire management regime as in most countries [32-36]. The reasons given are that these fire reduce the quantity of biomass and therefore the risk of intense fire and create habitat heterogeneity. The late fire regime is generally not recommended because it has a negative impact on trees [25].

The canopy stratum at Lamto is composed for over 90\% adult trees belonging to four species [37]: Bridelia ferruginea Benth (Phyllantaceae) Crossopteryx febrifuga (Afzel. ex G. Don) Benth. (Rubiaceae), Cussonia arborea Hochst. ex A. Rich. (Araliaceae) and Piliostigma thonningii (Schum.) Milne-Redhead (Caesalpiniaceae). Some species such as Annona senegalensis Pers. (Annonacea) are sometimes present as resprout or small shrubs. Others, such as Terminalia schimperiana Hochst. (Combretaceae), are mainly in woody savannas.

\subsection{Study Plots}

This study was conducted in 2009 and 2010 on two plots of shrubby savanna, of 3.72 ha each $(310 \mathrm{~m} \times 120$ $\mathrm{m})$. Each plot was divided into seven subplots $(80 \mathrm{~m} \times$ $30 \mathrm{~m}$ ) separated by $10 \mathrm{~m}$-wide fire-breaks (Figure 1). Three subplots were subjected to normal fire (that occurs in January) and three others to a late fire (in April). For each group of subplots, they were three levels of grass biomass: C0, C1 and C2 (Figure 2). On C0, grasses were removed and distributed on C2 (where grass biomass was then considered doubled). On C1, grass biomass is as the surround savanna. Only C1 and C2 were burnt. The seventh subplot represented the control, where there was no slashing and no burning (UBS, Unburned Site).

\subsection{Fire Intensity Measurements}

According to [38], fire intensity is a measure of the energy released along the fire front, and is defined as the product of the heat yield of the fuel $(\mathbf{H})$, the weight of standing fuel consumed in the flaming zone $(\mathbf{W})$, and the rate of forward spread of the fire line or perimeter $(\mathbf{R})$. This fire intensity was determined on subplots C1 and C2 that have burned, and during the two different fire regimes.

$$
\mathrm{I}(\mathrm{kW} / \mathrm{m})=\mathbf{W H R}
$$

$\mathbf{H}$ : is a constant measured in laboratory. Its recommended value is $18,700 \mathrm{KJ} \cdot \mathrm{kg}^{-1}$ [39]; $\mathbf{W}\left(\mathrm{kg} \cdot \mathrm{m}^{-2}\right)$ is the quantity of fuel. It was determined by weighting grass samples (fresh grasses are cut in $1 \mathrm{~m}^{2}$ quadrat at four points distributed over each subplot C1 and C2) after oven drying at $60^{\circ} \mathrm{C}$ for 72 hours; for $\mathbf{R}\left(\mathrm{m} \cdot \mathrm{s}^{-1}\right)$ measurement, stakes were set at $10 \mathrm{~m}$ intervals on the different subplots. Fire spread was measured thereby for each of the eight intervals obtained as the time needed for the fire front to cover the distance between two successive stakes. This time determined using a stopwatch and the 


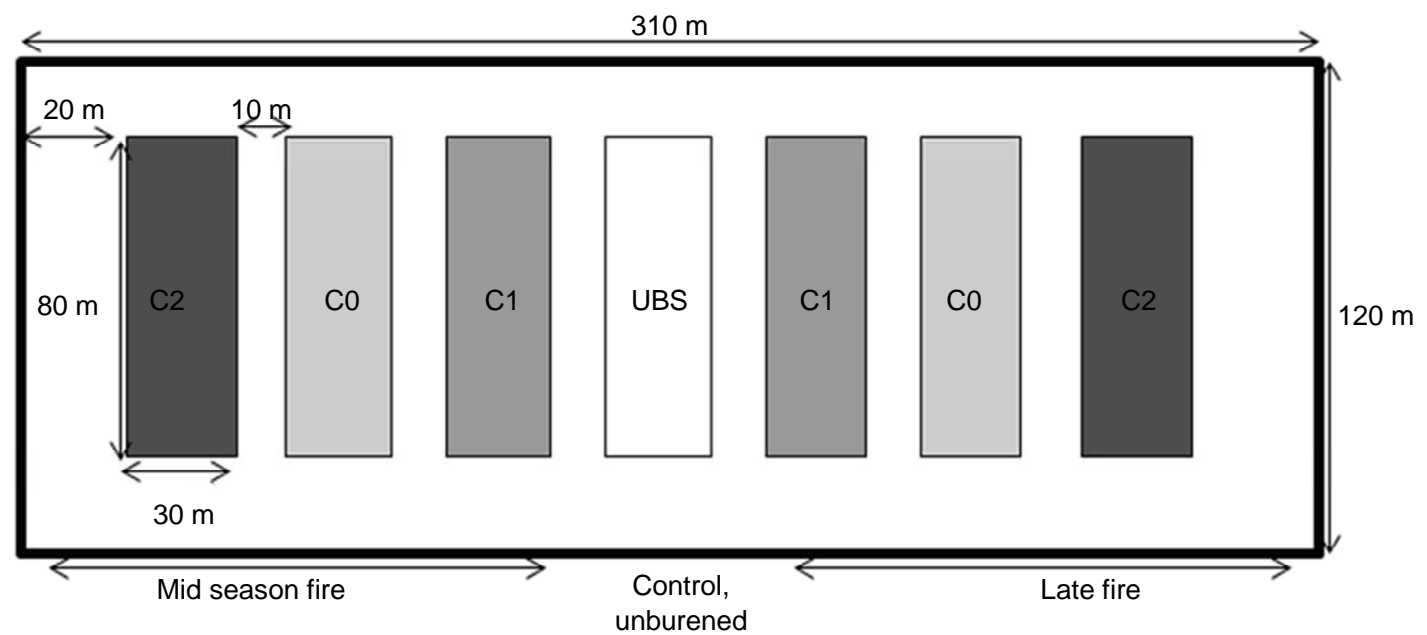

Figure 1. Experimental design of fire experiment. On C0, grasses were removed and distributed on C2 (where grass biomass was considered doubled). Only C1 (normal biomass) and C2 were burnt. The seventh subplot represented the control, where there were no slashing and no burning (UBS).
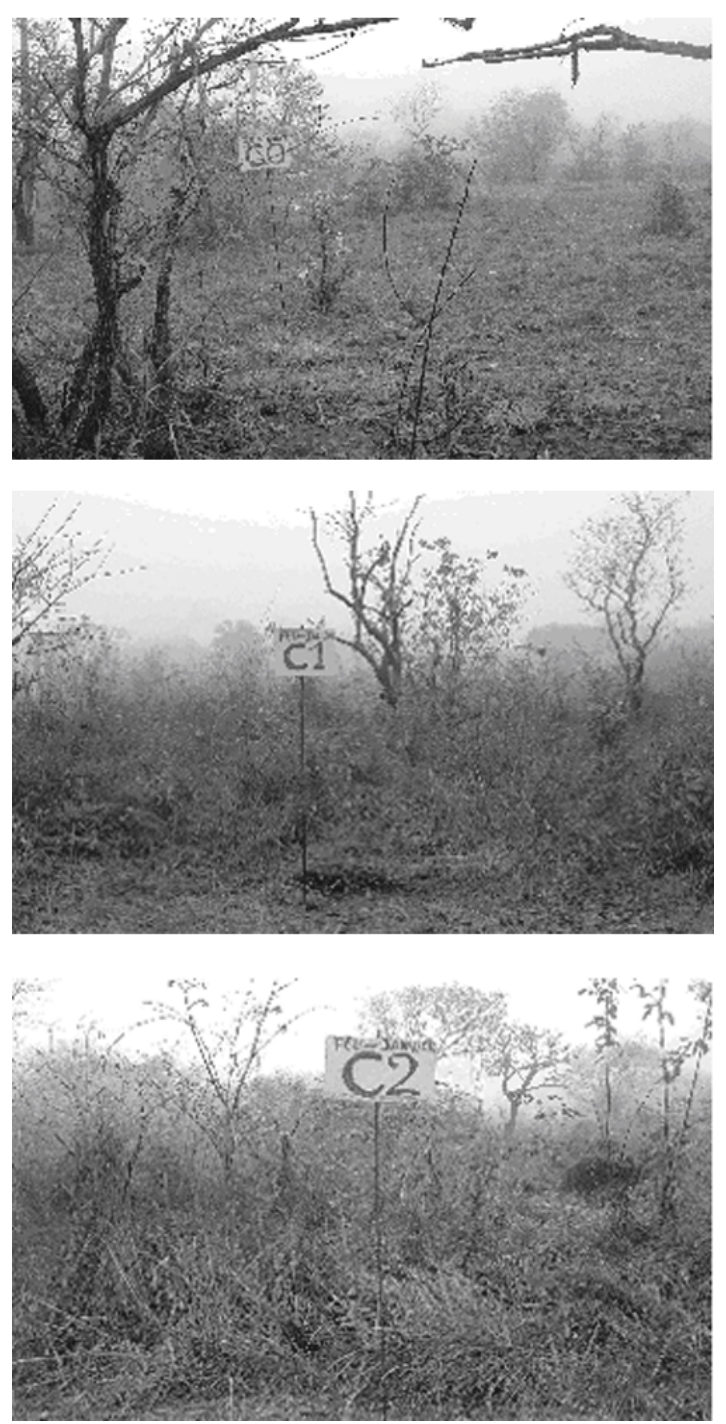

Figure 2. Subplots with different grass biomass level. average time was calculated for each subplot during the two different fire regimes experiments.

\subsection{Impact of Fire on Grasses Regrowth}

This experiment aims at determining the speed of grasses regrowth according to the fire intensity and its regime. The height of the grass layer was measured using a herbometer (Figure 3), this 3, 6 and 9 months after the different fire regime. This regrowth was measured at four points of each subplot C1, C2 and C0 (as control).

\subsection{Damage Caused by Fire on Trees}

The purpose of this study is to evaluate debarking caused by fire in order to correlate it to the fire intensity and fire regime. After the fire, all the damages on trees were recorded, whether related to an immediate fire (Figure 4(a)) or previous ones (Figure 4(b)). The main savanna species were considered: B. ferruginea, $C$. febrifuga, $C$. barteri and $P$. thonningii. The impact of fire on young and adult trees was evaluated by detecting areas debarked by fire on the main branches. Fire can cause damage in all directions for straight trees [40] or to the leeward side of the branch or trunk [26,41]. When the trunk or branch was debarked or presented an external opening, we recorded whether trees were leaning and whether debarked parts or external openings were facing downwards or upwards. Trees were considered leaning if more than $30^{\circ}$ from the vertical. According to [41-44], these debarked parts could be entry points for termites into trees and could be easily burnt at the next fire because not protected by the bark. According to the scenario proposed by [26], the external openings observed on trees would start by debarking which would allow termites to enter into tree trunks. Once termites have 


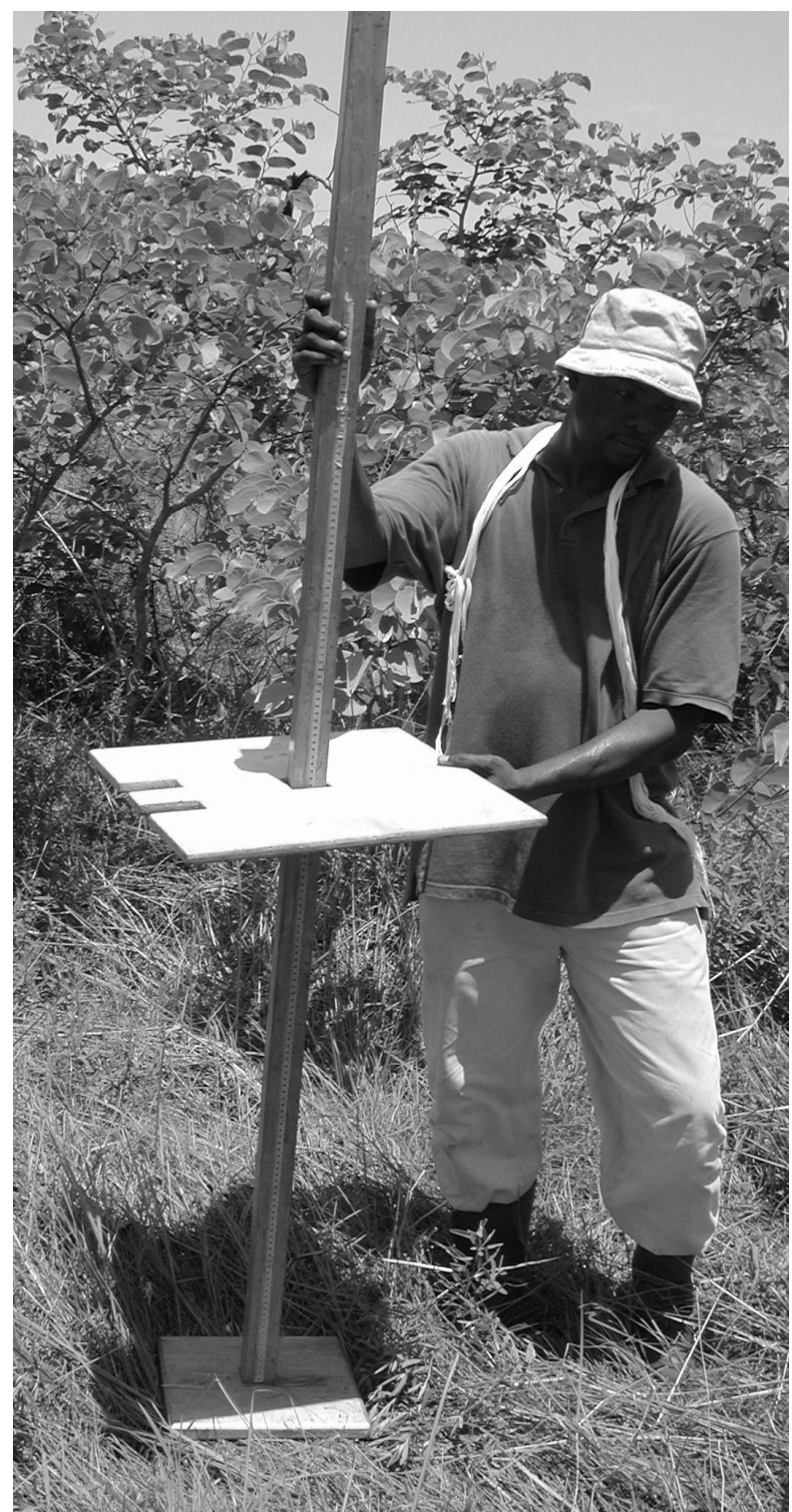

Figure 3. Herbometer used to measure the height of grass stratum. entered the trunk and started piping, they restrict their action to heartwood. Once the tree is hollowed by termites, unless the internal cavity is very large, a single fire could cause an external opening (Figure 4(c)). These external openings are responsible for an increase in tree mortality through mechanical trunk breakage [45, N'Dri "unpublished data").

\subsection{Statistical Analyses}

Statistical analyzes were processed using the $\mathrm{R}$ software (http://www.r-project.org/). The linear model (lm) was used to analyse 1) the change in the fuel quantity according to the treatment ( $\mathrm{C} 1$ and $\mathrm{C} 2)$ and the fire regime (mid-season and late fire); 2) the intensity of fire according to its regime; 3 ) the height of grass regrowth according to the treatment ( $\mathrm{C} 0, \mathrm{C} 1$ and $\mathrm{C} 2)$, the fire regime and the measurement period (3, 6 and 9 months after the fire). The test ranks sign of Wilcoxon was used to analyse the intensity variation as a function of treatment (C1 and C2). The generalized linear model (glm) was used to analyse the frequency of debarked trees according to the different species and the development stages. Chi-square tests were used 1) to test the distribution of debarking parts and opening directions; and 2) to test its correlation with the leaning direction.

\section{RESULTS}

\subsection{Fire Intensity}

The C2 treatment led to a much higher fuel for this treatment (ANOVA, $\mathrm{F}_{1,6}=14.99$ and $\mathrm{p}=0.001$, Table 1). These effects in turn affected fire intensity, which increased with the fuel quantity (Test rank sign of Wilcoxon, $\mathrm{p}<0.05, \alpha=5 \%$ ) and is independent on the fire regime (ANOVA, $\mathrm{F}_{1,4}=1.770, \mathrm{p}=0.254$, Table 2). There is no fuel variation between the burnt plots at different fire date (ANOVA, $\mathrm{F}_{1,6}=0.015$ and $\mathrm{p}=0.906$ ).
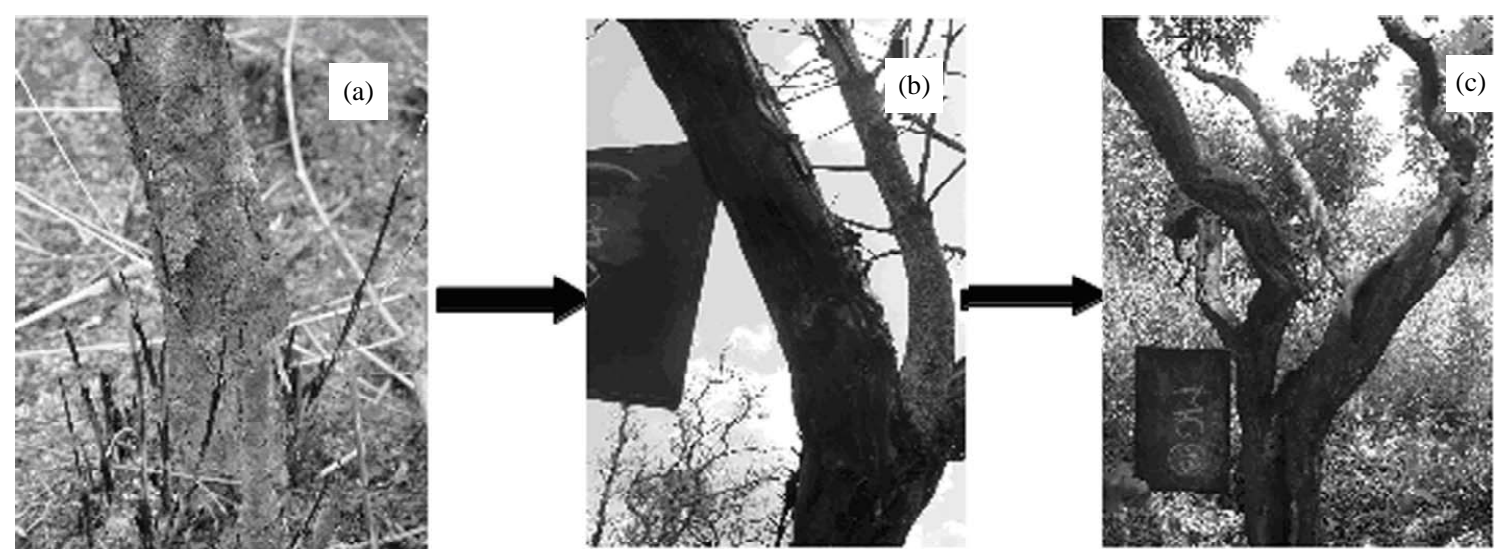

Figure 4. Different stages of damages caused by fire. (a) Scorching of the year; (b) scorching following many fires facing downward at the leaning side; (c) Exposition of internal cavities at the downward face of branch leaning side. 


\subsection{Impact of the Fire on the Regrowth of Grasses Layer}

The regrowth speed of grasses varied with the level of fuel used (treatment): C0, C1 and C2 (ANOVA, $\mathrm{F}_{2,126}=$ 8.04 and $p=0.0005)$, and the measurement period: 3,6 and 9 months after each fire (ANOVA, $F_{2,126}=411.59$ and $\mathrm{p}<0.001)$. Regrowth varied according to the inter-

Table 1. Grass biomass (fuel) quantity according to fire regime treatement.

\begin{tabular}{ccc}
\hline Fire regimes & Subplots & Fuel quantity $\left(\mathbf{K g} \cdot \mathbf{~ m}^{-2}\right)$ \\
\hline Mid season fire & C2 & $2.37 \pm 0.7$ \\
Mid season fire & C1 & $1.10 \pm 0.25$ \\
Late fire & C2 & $2.21 \pm 0.36$ \\
Late fire & C1 & $1.33 \pm 0.1$ \\
\hline
\end{tabular}

Table 2. Mean intensities of fire according to fire regime and fuel quantity.

\begin{tabular}{ccc}
\hline Fire regimes & Subplots & Fire intensities $\left(\mathbf{K W} \cdot \mathbf{m}^{-1}\right)$ \\
\hline Mid season fire & C2 & $4421 \pm 2278$ \\
Mid season fire & C1 & $1510 \pm 960$ \\
Late fire & C2 & $2339 \pm 1353$ \\
Late fire & C1 & $1007 \pm 429$ \\
\hline
\end{tabular}

action between fuel level and the measurement period (ANOVA, $\mathrm{F}_{4,126}=2.78$ and $\mathrm{p}=0.03$ ). It was only after 9 months that the difference in regrowth was significant among treatments (ANOVA, $\mathrm{F}_{2,42}=7.49$ and $\mathrm{p}=0.0016$ ); on average of $70.25 \mathrm{~cm}$ height, $67.31 \mathrm{~cm}$ and $63.56 \mathrm{~cm}$ respectively for treatments $\mathrm{C} 2, \mathrm{C} 1$ and $\mathrm{C} 0$. The heights of grasses 3 months after the fire in mid-season are higher than those observed for the same duration after the late fire (ANOVA, $F_{1,42}=9.36$ and $p=0.004$ ). This same tendency is observed 9 months after each type of fire (ANOVA, $\mathrm{F}_{1,42}=29.39$ and $\mathrm{p}<0.001$ ).

\subsection{Damages Caused by Fire on the Woody Stratum}

The recent debarking observed following the mid-season fire and caused by it showed that a single fire rarely caused debarking on trees: at most, in double fuel load (C2), $8 \%$ of trees were debarked while the fire under normal fuel (C1) did not cause any debarking.

Older debarking, resulting from several previous fires affected $48 \%$ of the sampled trees. The proportion of these trees varied with species, C. febrifuga (82\%) was significantly more often debarked (deviance $=63.846, \mathrm{df}$ $\left.=3, \chi^{2}=100.657, \mathrm{p}=0.001\right)$ than $P$. thoningii, $C$. barteri and $B$. ferruginea, respectively, 45\%, 35\% and 32\% (Figure 5). Moreover, adult trees were more often significantly debarked (65\%) than young trees (35\%) (deviance $\left.=31.448, \mathrm{df}=1, \chi^{2}=101.015, \mathrm{p}=0.004\right)$.

After observation of 580 main branches, 57\% were debarked. The directions in which these branches were debarked were not randomly oriented. Most of them

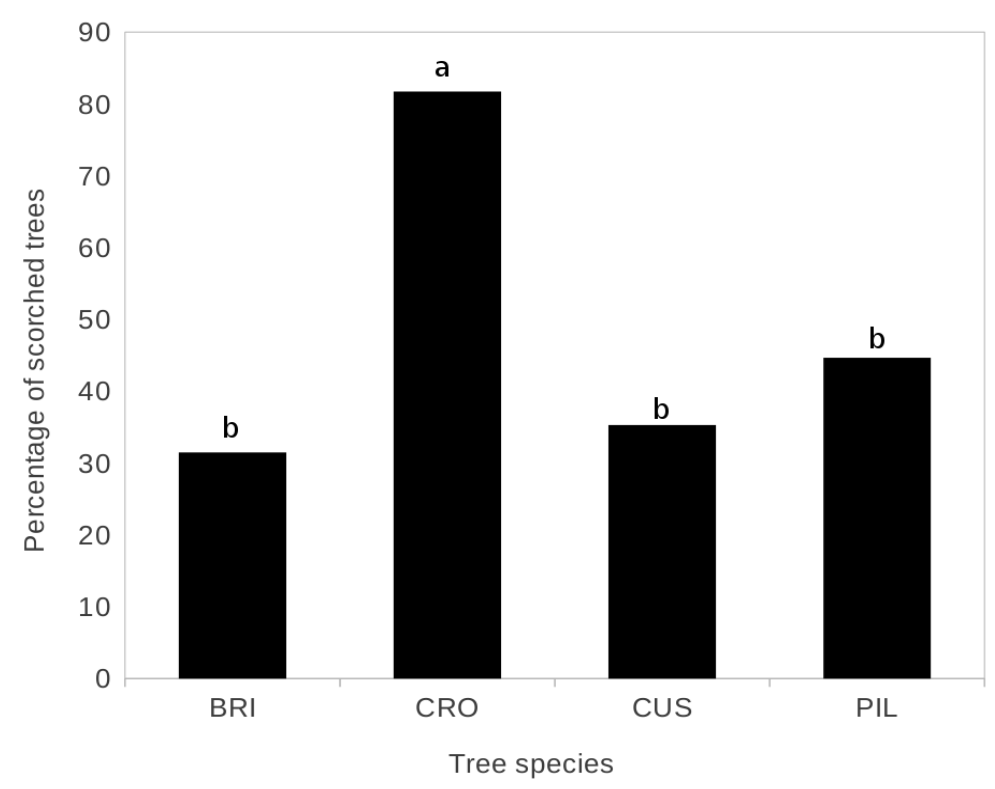

Figure 5. Proportion of scorched trees according to the different species. Test post-hoc of TukeyHSD. BRI: Bridelia ferruginea; CRO: Crossopteryx febrifuga; CUS: Cussonia arborea; PIL: Piliostigma thonningii. 
(89\%) had their debarking facing downward at the leaning side $\left(\chi^{2}=190.56\right.$, $\left.\mathrm{df}=1, \mathrm{p}<0.001\right)$. In addition, $66 \%$ of the leaned branches had external hollows. The majority of these branches (79\%) had their hollow facing downward at the leaning side of trees, this observation is statistically significant $\left(\chi^{2}=92.60\right.$, df $\left.=1, \mathrm{p}<0.001\right)$.

\section{DISCUSSION}

\subsection{Relation between Fire Intensity and Severity}

The average fire intensity did not vary according to the fire regime (mid-season and late fires). Indeed, [46-48] as well as studies conducted in Kakadu National Park [35], showed that timing is likely to be an important factor determining the ecological effects of fire, regardless of intensity. The impact of fire on tree survival is more related to physiological stage of the tree at the fire moment than the intensity of this fire. For example, it may be that savanna fires have the greatest impact on plant during periods of active growth (late fire) because carbohydrate and nutrient reserve have been depleted [7, $46,49,50]$. Whereas the period of mid-season fires (midJanuary) coincides with the senescence phase of the epigeous parts of plants and the vegetative activity is lower.

As expected, the fire intensitiy values are higher for double fuel load than simple fuel load. Indeed, abundant biomass on the sites that remain unburned for years increases the risk of fire of very high intensities [51,52].

\subsection{Impact of the Intensity and Regime of Fire on Vegetation}

According to [2], fire intensity can cause tree death or damage to them through the debarking of trunks or the burning of leaves or buds. Here we show that in the long term, fire causes the debarking of $48 \%$ of trees. These debarked areas would favor termites entry into trees [26, 41-44] to cause internal hollow, exposed later by fire action [26]. Once exposed, tree trunk mechanical resistance is affected [45].

The tree species $C$. febrifuga was most subjected to hollowing: $84 \%$ of adult trees were hollowed [26]. It is also the one with the most debarked individuals: $82 \%$. As the debarked branch parts, the external cavity facing downward at the leaning side of the trees. This shows the link between debarking and hollowing.

The fire intensity affects the rate of regrowth of grasses. Nine months after the mid-season and late fires, grass heights on compartments C2 were higher than that on $\mathrm{C} 1$, which in turn was higher than that on $\mathrm{C} 0$. This suggests a stimulation of growth where the fuel was doubled, that through the ash resulting from burning grasses.

The late fire decreased the regrowth rate of grasses compared to mid-season fire in spite of a supposedly better water supply due to the onset of the rainy season. This trend is contrary to that observed by [8], which showed that grasses regrowth was higher after the late fire than the mid-season one (1 - 250 days following the fire). He explained this higher regrowth following the late fire in April, by the fact that the rainy season which extends from March to July, promotes growth of grasses after this fire regime, while the mid-season fire (January) took place during the long dry season which runs from December to February. The contrary tendency observed in this study, could be explained by the fact that the rainy season tends to shift more and more due to climate change. Indeed, rainfall is very variable from one year of study to another. In 1963, when Monnier [8] measured the speed of grass regrowth, rainfall after mid-season fire was lower than after the late one. About 40, 150 and 100 mm of rain respectively in February, March and April and approximately 400 and 300 respectively in June and July following the late fire. The highest rainfall following the late fire has indeed favored greater regrowth of grasses. However, during the year 2009, rainfall following the mid-season fire was higher than after the late fire. Rainfalls were 177, 158 and 128 mm in February, March and April, respectively following the mid-season fire and 122 and 169 in June and July respectively, following late fire. The opposite trend about rainfall in this study compared to that of Monnier [8] may explain the faster grass regrowth following the mid-season. These results suggest that abundant rainfall in a year, would favor higher fire intensity the following year. Now, if the climate is not conducive to good combustion of vegetation for a year, it would through the accumulated biomass, lead to a high intensity of fire the following year. This high fire intensity will in turn promote regrowth of more biomass the following year. The climate of the year and meteorological conditions before the fire control in fact, the occurrence and speed of fire spread in almost all ecosystems [2]. The climatic conditions of the year, in fact determine the amount of fuel that burns.

\section{CONCLUSION}

This study reveals that fire intensity does not vary significantly from one regime to another (mid-season and late fires) but depends on the level of fuel. The rate of regrowth of grasses following fire also varies depending on the level of fuel: grasses on sites with double fuel load grow faster than those on the sites with simple fuel load. The mid-season fire regrowth ensures greater biomass than the late fire. The impact of fire on mature trees is also linked to its intensity; they are more commonly damaged in double-fuelled sites compared to simple fuelled-sites. There is a positive feedback between fuel load and grass production: grass regrowth tend to be 
faster following more intense fires; if this yields a higher grass biomass at the end of the growing season, then locally the fire will be more intense. If a low intensity fire breaks this feedback loop, dead grass biomass will accumulate and yield a more intense fire the following year. We can thus conclude that the grasses of Guinea savannas maintain a resilient high-intensity fire regime. The fire remains the recommended mid-season fire regime, because supports a significant regrowth of herbaceous biomass fires that promotes more and more important, ensuring the maintenance of balance between grasses and trees.

\section{ACKNOWLEDGEMENTS}

This study was conducted as part of the RIPIECSA-project in Côte d'Ivoire. Thanks to all the Lamto reserve students who helped us during handling for determining the intensity of the fire. We are grateful to Kanvaly Dosso, N'Golo Kone, Kone Mouamadhou, Tamia Kouakou, Evelyne Toure, Josiane Ahoussi, Tra-Bi. Thank you to all the reserve technicians who have also helped us during this work. Among them, we especially thank Francois N'Guessan and Kounan Honoré who accompanied us during all fieldwork. We are grateful to Karen Tinland for her contribution in editing the text.

\section{REFERENCES}

[1] Cochrane, M.A. (2009) Tropical fire ecology: Climate change, land use, and ecosystem dynamics. Springer, Berlin, New York.

[2] Johnson, E.A. (1992) Fire and vegetation dynamics. Studies from the North American boreal forest. Cambridge University Press, New York. doi:10.1017/CBO9780511623516

[3] Archer, S. (1995) Tree-grass dynamics in a Prosopis savanna parkland-thornscrub: Reconstring the past and predicting the future. Ecoscience, 21, 83-99.

[4] Williams, R.J., Duff, G.A., Bowman, J.S. and Cook, G.D. (1996) Variation in the composition and structure of tropical savannas as a function of rainfall and soil texture along a large-scale climatic gradient in the northern territory, Australia. Journal of Biogeography, 23,747-756. doi:10.1111/j.1365-2699.1996.tb00036.x

[5] Skowno, A.L., Midgley, J.J., Bond, W.J. and Balfour, D. (1999) Secondary succession in Acacia nilotica (L.) savanna in the Hluhluwe Game Reserve, South Africa. Vegetation, 145, 1-9. doi:10.1023/A:1009843124991

[6] Ward, D. (2005) Do we understand that causes of bush encroachment in African savannas? African Journal of Range and Forage Science, 22, 101-105. doi:10.2989/10220110509485867

[7] Andersen, N.A., Cook, G.G. and Williams, R.J. (2003) Fire in tropical savannas, the Kapalga experiment. Ecological Studies, 169, 195.

[8] Monnier, Y. (1968) Les effets des feux de brousse sur une savane préforestière de Côte d'Ivoire. Etudes Eburnéennes, 9, 1-260.
[9] Stronach, N.R.H. and MacNaughton, S.J. (1989) Grassland fire dynamics in the Serengeti ecosystem, and a potential method of retrospectively estimating fire energy. Journal of Applied Ecology, 26, 1025-1033. doi:10.2307/2403709

[10] Bessie, W.C. and Johnson, E.A. (1995) The relative importance of fuels and weather on fire behavior in subalpine forests. Ecology, 76, 747-762. doi:10.2307/1939341

[11] Hoffmann, W.A., Orthen, B. and Do Nascimento, P.K.V. (2003) Comparative fire ecology of tropical savanna and forest trees. Functional Ecology, 17, 720-726. doi:10.1111/j.1365-2435.2003.00796.x

[12] Mordelet, P., Abbadie, L. and Menaut, J.C. (1993) Effects of tree clumps on soil characteristics in a humid savanna of West Africa (Lamto, Côte d'Ivoire). Plant and Soil, 153, 103-111. doi:10.1007/BF00010549

[13] Swaine, M.D., Hawthorne, W.D. and Orgle, T.K. (1992) The effects of fire exclusion on savanna vegetation at Kpong, Ghana. Biotopica, 24, 166-172. doi:10.2307/2388670

[14] Russell-Smith, J., Whitehead, P.J., Cook, G.D. and Hoare, J.L. (2003) Response of Eucalyptus-dominated savanna to frequent fires: Lessons from Munmarlary, 1973-1996. Ecological Monographs, 73, 349-375. doi:10.1890/01-4021

[15] Bond, W.J. and Keeley, J.E. (2005) Fire as a global 'herbivore': The ecology and evolution of flammable ecosystems. Trends in Ecology and Evolution, 20, 387-394. doi:10.1016/j.tree.2005.04.025

[16] Sankaran, M., Hanan, N.P., Scholes, R.J., Ratnam, J., Augustine, D.J., Cade, B.S, Gignoux, J., Higgins, S.I., Le Roux, X., Ludwig, F., Ardo, J., Banyikwa, F., Bronn, A., Bucini, G., Caylor, K.K., Coughenour, M.B., Diouf, A., Ekaya, W., Feral, E.C., February, J.C., Frost, P.G., Hiernaux, P., Hrabar, H., Metzger, K.L., Prins, H.H., Ringrose, S., Sea, W., Tews, J., Worden, J. and Zambatis, N. (2005) Determinants of woody cover in African savannas. $\mathrm{Na}$ ture, 438, 846-849. doi:10.1038/nature04070

[17] Menaut, J.C., Abbadie, L., Lavenu, I., Loudjani, P. and Podaire, A. (1991) Biomass burning. In: Levine, J., Ed., West African Savannas, Global Biomass Burning, MIT Press, Cambridge, 133-141.

[18] Moore, P.H.R., Gill, A.M. and Kohnert, R. (1995) Quantifying bush fires for ecology using two electronic devices and biological indicators. Calmscience Supplement, 4, 8387.

[19] Moncrieff, G.R., Kruger, L.M. and Midgeley, J.J. (2008) Stem of Acacia nigrescens mortalité induced by the synergistic effects of elephants and fire in Kruger National Park, South Africa. Journal of Tropical Ecology, 24, 655662. doi:10.1017/S0266467408005476

[20] Levick, S.R., Asner, G.P., Kennedy-Bowdoin, T. and Knapp, D.E. (2000) The relative influence of fire and herbivory on savanna vegetation three-dimensional structure. Biological Conservation, 142, 1693-1700. doi:10.1016/j.biocon.2009.03.004

[21] Smit, I.P.J., Asner, G.P., Govender, N., Kennedy-Bowdoin, T., Knapp, D.E. and Jacobson, J. (2010) Effects of fire on 
woody vegetation structure in African savanna. Ecological Applications, 20, 1865-1875.

doi:10.1890/09-0929.1

[22] Bond, W.J. and Midgley, J.J. (2001) Ecology of sprouting in woody plants: The persistence niche. Trends in Ecology and Evolution, 16, 45-51. doi:10.1016/S0169-5347(00)02033-4

[23] Holdo, R.M. (2005) Stem mortality following fire in Kalahri sand vegetation: Effects of frost, prior damage, and tree neighbourhoods. Plant Ecology, 180, 77-86. doi:10.1007/s11258-005-2796-4

[24] N'Dri, A.B. (2011) Interraction termite-feu et dynamique de la végétation en savane: Lamto (Côte d’Ivoire). Ph.D. Thesis, University Paris VI, Paris.

[25] Williams, R.J., Cook, G.D., Gill, A.M. and Moore, P.H.R. (1999) Fire regime, fire intensityand tree survivals in a tropical savanna in northern Australia. Australian Journal of Ecology, 24, 50-59. doi:10.1046/j.1442-9993.1999.00946.x

[26] N’Dri, A.B., Gignoux, J., Konaté, S., Dembélé, A. and Aïdara, D. (2011) Origin of trunk damage in West African savanna trees: The interaction of fire and termites. Journal of tropical Ecology, 27, 269-278. doi:10.1017/S026646741000074X

[27] Vines, R.G. (1981) Physics and chemistry of rural fires. In: Gill, A.M., Groves, R.H. and Noble, I.R., Eds., Fire and the Australian Biota, Australian Academy of Sciences, Canberra, 129-150.

[28] Hogenbirk, J.C. and Sarrazin-Delay, C.L. (1995) Using fuel to estimate plant ignitability characteristics for fire hazard reduction. Water, Air and Soil Pollution, 82, 161170. doi:10.1007/BF01182830

[29] McAlpine, R.S. (1995) Testing the effect of fuel on fire spread rat consommation. International Journal of Wildland Fire, 5, 143-152. doi:10.1071/WF9950143

[30] Lamotte, M. and Tireford, J. (1988) The climate of the savanna of Lamto (Ivory Coast) and its place in the climate of West Africa. Researchers Work Lamto (RCI), 8, $1-146$.

[31] Pagney, P. (1988) Le climat de Lamto (Côte d'Ivoire). In: Lamotte, M. and Tireford, J.L., Eds., Le Climat de la Savane de Lamto (Côte d'Ivoire) et sa Place Dans les Climats de l'Ouest Africain, Travaux de Recherche des Chercheurs de Lamto, 31-79.

[32] Vuattoux, R. (1969) Les feux à Lamto en 1969. Bulletin de Liaison des Chercheurs de Lamto Mars, 9-10.

[33] Gillon, D. (1983) The fire problem in tropical savannas. In: Bourliere, F. Ed., Tropical Savannas, Volume 13 of Ecosystems of the World, Elsevier, Amsterdam, 617-642.

[34] Russell-Smith, J. (1995) Fire management. In: Press, A.J., Lea, D.A.M., Webb, A.L. and Graham, A.D., Eds., Kakadu, Natural and Cultural Heritage and Management, Anstralian Nature Conservation Agency/North Australian Research Unit, Darwin, 217-223.

[35] Kakadu Board of Management and Australian Nature Conservation Agency (1996) Kakadu national park draft plan of management, NT, Jabiru.

[36] Zida, D., Sawadogo, L., Tigabu, M., Tiveau, D. and Oden,
P.C. (2007) Dynamics of sapling population in savanna woodlands of Burkina Faso subjected to grazing, early fire and selective tree cutting for a decade. Forest Ecology and Management, 243, 102-115. doi:10.1016/j.foreco.2007.02.013

[37] Menaut, J.C. and Cesar J. (1979) Structure and primary structure of Lamto savannas productivité (Ivory Coast). Ecology, 60, 1197-1210. doi:10.2307/1936967

[38] Byram, G.M. (1959) Combustion of forest fuels. In: Davis, K.P., Ed., Forest Fire Control and Use, McGraw-Hill, New York, 61-89.

[39] Alexander, M.E. (1982) Calculating and interpreting forest fire intensities. Canadian Journal of Botany, 60, 349357. doi:10.1139/b82-048

[40] Gill, A.M. (1974) Toward an understanding of fire-scar formation: Field observation and laboratory simulation. Forest Science, 20, 198-205.

[41] Whitford, K.R. (2002) Hollows in jarrah (Eucalyptus marginata) and marri (Corymbia calophylla) trees. I. Hollow sizes, tree attributes and ages. Forest Ecology and Management, 160, 201-214. doi:10.1016/S0378-1127(01)00446-7

[42] Perry, D.H., Lenz, M. and Watson, J.A.L. (1985) Relationship between fire fungal rots and termite damage in Australian forest trees. Australian Forestry, 48, 46-53.

[43] Gibbons, P. and Lindenmayer, D.B. (1997) Conserving hollow-dependent fauna in timber-production forests New South Wales National Parks and wildlife services. Environmental Heritage Monograph Series No. 3, Sydney.

[44] Whitford, K.D. and Williams, M.R. (2002) Hollows in jarrah (Eucalyptus marginata) and marri (Corymbia calophylla) trees. II. Selecting trees to retain for hollow dependent fauna. Forest Ecology and Management, 160, 215-232. doi:10.1016/S0378-1127(01)00447-9

[45] Mattheck, C. and Kubler, H. (1995) Wood: The internal optimization of trees. Springer Verlag, Berlin.

[46] Caesar, J. (1971) Quantitative study of the herbaceous layer of the savanna of Lamto (Ivory Coast Average). Ph.D. Thesis, University Paris VI, Paris.

[47] Caesar, J. (1991) Typology, diagnosis and evaluation of forage production ministerial training in tropical Africa. Fodder, 128, 423-442.

[48] Louppe, D., N’klo, O. and Coulibaly, A. (1995) Effect of bushfires on vegetation. Woods and Forests of the Tropics, 245, 59-74.

[49] César, J. (1992) Etude de la production biologique des savanes de Côte d'Ivoire et son utilisa-tion par l'homme. Biomasse, valeur pastorale et production fourragère. Ph.D. Thesis, University Paris VI, Paris.

[50] Riou, G. (1995) Le système savane et les grandes questions. L'herbe, l'arbre et l'homme en terres tropicales. Masson, Armand Collin, Paris.

[51] Gill, A.M., Hoare, J.R.L. and Cheney, N.P. (1990) Fires and their effects in the wet-dry tropics of Australia. In: Goldammer, J.G., Ed., Fire in the Tropical Biota, Ecosystem Processes and Global Challenges, Springer-Verlag, Berlin, 159-178.

[52] Midgley, J.J., Balfour, D. and Govender, N. (2006) Is 
carry-over of grass biomass between years determining important in savanna fire regimes? African Journal of
Range Forage Science, 23, 81-83. doi:10.2989/10220110609485890 